\title{
Modeling of Influence of Resourcing Factors on Gross Regional Product
}

\author{
Larisa A. Tretyakova, Marina V. Vladika, Tatyana A. Vlasova, Oksana V. Vaganova, Denis P. \\ Solntsev
}

\begin{abstract}
The transformation processes occurring in the country, causing the uneven development of individual regions, are characterized by increased competition at the regional level. The consequence of the acquisition of economic independence by the regions of the Russian Federation is a reappraisal of its current position and basic functions, the implementation of which is aimed at asserting themselves and strengthening their reliable position in the market and socio-economic spaces of the country by increasing competitive advantages. The formation of competitive advantages of the regions based on the resource potential in the conditions of market relations is the main condition for increasing the efficiency of regional socio-economic systems, predetermining both the sustainable development of the region by ensuring a high level of economic performance and the life quality of the population, and further prospects for the development of environmental and institutional components.

The purpose of the study is to assess the degree of influence of key components of the region's resource potential on the gross regional product per capita as the main recognized indicator of regional development and regional competitiveness based on building an econometric model with the subsequent development of a projection of changes in the indicator of a specific region under the influence of quality and quantity resource potential.
\end{abstract}

Keywords : regional development, gross regional product, resource potential, modeling, projection scenario.

\section{INTRODUCTION}

The problem of projection of socio-economic development and raising the level of competitiveness of Russian regions is important and is widely discussed in the works of modern researchers (Gerasimov, Tretyakova, 2017, Kuznetsova, Kocheva, Matev, 2015, Tretyakova, Vlasova and etc., 2018). The basis for determining an effective regional development strategy should be a multidimensional assessment of the socio-economic situation in the regions (Valentey, Bakhtizin, Bukhvald, Kolchugina, 2014, Savaley, 2017) in complex with the assessment of the resource potential, as well as the construction of scenario predictions, allowing to vary the managerial impact (Kuklin, Korobkov, 2018).

Revised Manuscript Received on July 22, 2019.

* Correspondence Author

Larisa A. Tretyakova, Belgorod State University, Russia, 308015 , Belgorod, Pobedy St., 85

Marina V. Vladika, Belgorod State University, Russia, 308015, Belgorod, Pobedy St., 85 .

Tatyana A. Vlasova, Belgorod State University, Russia, 308015, Belgorod, Pobedy St., 85.

Oksana V. Vaganova, Belgorod State University, Russia, 308015, Belgorod, Pobedy St., 85

Denis P. Solntsev, Belgorod State University, Russia, 308015, Belgorod, Pobedy St., 85
Projection scenario is recognized as one of the effective tools used to predict the possible development trends of the phenomena under study. The basis for the preparation of projection scenarios is the construction of projection models that reflect the possible directions of changes in the phenomena under the influence of the most important factors and the arsenal of tools of the control system. The prediction of changes in the level of gross regional product per capita as the main recognized indicator of regional development and regional competitiveness under the influence of the qualitative level and quantitative composition of the resource potential of the regions serves as a basis for developing socio-economic programs for regional development at various levels and a key guideline for their implementation.

\section{MATERIALS AND METHODS}

Currently, one of the most used methods for predicting the qualitative change in gross regional product per capita under the impact of resource potential remains the method of multifactorial correlation and regression modeling, the use of which allows to identify the main factors influencing the resultant attribute, assess the strength of their influence and make a model used to make factor predictions.

Conducting multivariate modeling includes the following phases: the choice of factor indices that affect the performance indicator; the formation of a homogeneous set; the choice of the form of the equation to reflect the patterns of formation of the effective indicator, depending on the influence of factor indices; check of connection factors for the presence of multicollinarity; determining the closeness of the correlation between the factor indices and the effective indicator with the subsequent evaluation of the statistical reliability of the indicators of communication and the adequacy of the model.

The analytical base of the research was made up of official statistical data in the context of subjects of all federal districts of the Russian Federation, data processing and analysis was carried out using the statistical analysis software package Statistica 7.0.

\section{RESULTS AND DISCUSSION}

Before directly starting to build a multi-factor econometric model of the influence of factors on the resource availability of the region on the gross regional product per capita, the dynamics of the development of this indicator for 2010-2017. in terms of federal districts will be characterized (Table 1). 
Table 1. Dynamics of the gross regional product per capita by federal districts of the Russian Federation in 2010-2017

\begin{tabular}{|c|c|c|c|c|c|c|c|c|c|c|}
\hline & 2010 & 2011 & 2012 & 2013 & 2014 & 2015 & 2016 & 2017. & $\left|\begin{array}{l}2017 \text { to } \\
2010, \%\end{array}\right|$ & 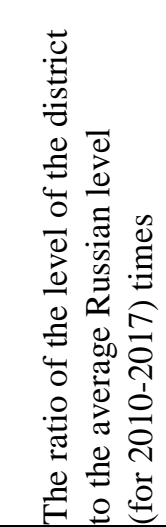 \\
\hline Russian Federation & 263829 & 317515 & 348642 & 377006 & 405148 & 449098 & 472050 & 510253 & 193.4 & 1.00 \\
\hline $\begin{array}{|ll|}\text { Central } & \text { Federal } \\
\text { District } & \\
\end{array}$ & 350204 & 417288 & 451517 & 494483 & 536608 & 580707 & 616493 & 666427 & 190.3 & 1.31 \\
\hline $\begin{array}{l}\text { North West Federal } \\
\text { District }\end{array}$ & 289611 & 350764 & 383339 & 403613 & 430131 & 520253 & 556775 & 588507 & 203.2 & 1.12 \\
\hline $\begin{array}{|ll|}\text { South } & \text { Federal } \\
\text { District } & \\
\end{array}$ & 168773 & 200307 & 229215 & 256445 & 255076 & 283856 & 304870 & 326245 & 193.3 & 0.64 \\
\hline $\begin{array}{l}\text { North-Caucasian } \\
\text { Federal District }\end{array}$ & $\begin{array}{l}94915 . \\
3\end{array}$ & 112648 & 127042 & 146117 & 163950 & 176400 & 182558 & 190285 & 200.5 & 0.38 \\
\hline \begin{tabular}{|l|} 
Privolzhsky (Volga) \\
Federal District
\end{tabular} & 190720 & 236240 & 263976 & 284810 & 308995 & 339075 & 348227 & 372654 & 195.4 & 0.75 \\
\hline Ural Federal District & 423495 & 521192 & 583244 & 619541 & 662531 & 737316 & 767531 & 864540 & 204.1 & 1.65 \\
\hline $\begin{array}{|ll|}\begin{array}{l}\text { Siberian } \\
\text { District }\end{array} & \text { Federal } \\
\end{array}$ & 214402 & 249420 & 269171 & 287294 & 317785 & 353119 & 367222 & 401809 & 187.4 & 0.78 \\
\hline \begin{tabular}{|ll} 
Far East & Federal \\
District &
\end{tabular} & 334910 & 403573 & 431768 & 454144 & 516740 & 577684 & 599195 & 628172 & 187.6 & 1.26 \\
\hline
\end{tabular}

Source: compiled and calculated by authors based on data of Rosstat (In Russian)

The size of the gross regional product per capita in Russia in 2017 was 510,253 rub. and exceeded the 2010 level by 93.4\%. Presented data indicates a significant differentiation of the indicator by federal districts, which is a consequence of an even higher differentiation of the indicator by sub-federal units, and a relatively small difference in the rate of growth of the indicator for the period under review.

Then the econometric modeling should be studied. The gross regional product per capita as the main recognized indicator of regional development and regional competitiveness was chosen as an effective indicator.

As factor indices, indicators reflecting the resource potential of the region are used. The choice of factor indices is due to their logical connection with the effective indicator and the availability of official statistical data in the regions of the Russian Federation. In determining the factors, various authorial approaches were considered (Heon-Goo Kim, 2008, Howard-Grenville, 2016, Tretyakova, Tselyutina and etc., 2015, Vlasova, Glotov, 2018).

At the initial stage, the following factors are identified as factor indices: life expectancy at birth; natural growth rate per 1000 population; migration growth rate per 10,000 people; the ratio of the average per capita cash income of the population with the subsistence minimum; the proportion of the population with cash incomes below the subsistence minimum; employment rate; average monthly nominal accrued wages of employees of organizations; density of autoroads with hard surface; the degree of depreciation of fixed assets at the end of the year; volume of investments in fixed capital per capita; the share of investments in fixed assets to GRP; the share of domestic research and development costs in GRP; level of innovation activity of organizations; the proportion of unprofitable organizations.

During the verification of the pattern of distribution and homogeneity of the aggregate using descriptive statistics, the following factor indices were excluded from the aggregate: the rate of natural increase per 1000 population; migration growth rate per 10,000 people; density of public roads with hard surface; the share of investments in fixed assets to GRP; the share of internal research and development costs in the GRP, as well as a number of objects of observation: Amur Oblast, Arkhangelsk Oblast, Moscow, Jewish Autonomous Oblast, Magadan Oblast, Komi Republic, Sakha Republic (Yakutia), Tatarstan Republic, Sakhalin Oblast, Tyumen region, Chukotka Autonomous Region, Chuvash Republic, Chechen Republic.

The total complex of the sampled exponents is represented by 8 factor indices 69 region-wise.

Statistical evaluation of the indicators selected for the construction of the model is presented in Table 2 . 
Table 2. Statistical evaluation of indicators selected for building the model

\begin{tabular}{|l|l|l|l|l|l|l|}
\hline & & & & \\
Index & & & & \\
\end{tabular}

The absence of collinearity between the factor indices was confirmed by the analysis of the matrix of paired correlation coefficients.

In the course of building a multifactor correlation-regression model, the following equation was obtained:

$$
Y_{x}=-239388-1920 x_{1}-1229 x_{2}+6577 x_{a}+8 x_{4}
$$

The initial model, which reflects the influence on the size of the gross regional product per capita of 8 selected factors, is statistically reliable. The actual value of Fisher's F-criterion, equal to 72.75 , exceeds the critical value -8.60 for the significance level of 0.05 with the number of degrees of freedom 8 and 60 . The value of the multiple correlation coefficient is 0.95 , and indicates a strong correlation between the resultant and factor indices. The value of the coefficient of determination was 0.91 , considering the adjustment for the number of degrees of freedom - 0.89 and is evidence that $89 \%$ of the gross regional product per capita can be explained by the cumulative effect of the selected factor indices. But at the same time, the calculated $\beta$-coefficients indicate the fact that the individual factors included in the model, for which [ß] 0.1 have a weak connection with the resultant mark.

In order to determine the best regression equation

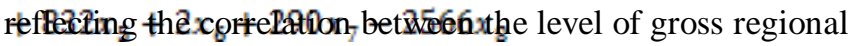
product per capita and factor characteristics, the method of step by step elimination of variables unreliable by Student's t-test was used. Conducting a multi-step regression analysis allowed us to successively exclude from the equation the factor indices with the lowest values of the t-criterion. Thus, the regression coefficients of the factor indices become significant in the third step after the exclusion of factors $\mathrm{x}_{7}$, $\mathrm{x}_{1}, \mathrm{x}_{2}, \mathrm{x}_{5}$ (Table 3 ).

Table 3. The final results of a step-by-step correlation and regression analysis of the interrelation between the yields of sugar beet and factors (with the exception of predictors from the regression model)

\begin{tabular}{|c|c|c|c|c|c|c|}
\hline \multicolumn{7}{|c|}{$\begin{array}{l}\text { Regression summary for dependent variable } \mathrm{Y}: \mathrm{R}=0.95 ; \mathrm{R}^{2}=0.90 ; \text { corrected } \mathrm{R}^{2}=0.89 \\
\mathrm{~F}(4.64)=146.88 ; \mathrm{p}<0.000000\end{array}$} \\
\hline Factors & Beta $(ß)$ & Constant error $\beta$ & $\begin{array}{l}\text { Regression } \\
\text { coefficient (b) }\end{array}$ & Constant error $b$ & $\mathrm{t}(64)$ & $\begin{array}{l}\text { Probability } \\
\text { level }(\mathrm{p})\end{array}$ \\
\hline $\mathrm{a}$ & & & -429087 & 81112.81 & -5.29001 & 0.000002 \\
\hline $\mathrm{x}_{3}$ & 0.280064 & 0.047959 & 8194 & 1403.22 & 5.83964 & 0.000000 \\
\hline $\mathrm{x}_{4}$ & 0.453255 & 0.049994 & 8 & 0.84 & 9.06619 & 0.000000 \\
\hline $\mathrm{x}_{6}$ & 0.383211 & 0.051012 & 2 & 0.22 & 7.51211 & 0.000000 \\
\hline $\mathrm{X}_{8}$ & -0.145085 & 0.039782 & -2983 & 817.90 & -3.64702 & 0.000534 \\
\hline
\end{tabular}

As a result, after eliminating unreliable factors, the multiple regression equation has taken the following form:

$$
\underline{Y}_{x}=-429087+8194 x_{\mathrm{a}}+8 x_{4}+2 x_{6}-2893 x_{\mathrm{g}}
$$

The final equation is statistically reliable, the value of Fisher's F-test was 146.88, which is well above the critical value of 4.64 for a significance level of 0.05 . The value of the coefficient of multiple correlation is 0.95 and is evidence of the strong link 


\section{Modeling of Influence of Resourcing Factors on Gross Regional Product}

between the resultant and factor indices. The resulting equation explains $89 \%$ of the variation in the level of gross regional product per capita, since the coefficient of determination is 0.90 and corrected for the number of degrees of freedom is 0.89 .

The construction of a multifactor model made it possible to distinguish four factors that sufficiently fully describe the total variation of the gross regional product per capita. At the same time, the level of gross regional product per capita is directly dependent on factors: the level of employment of the population, the average monthly nominal accrued wages of employees of organizations and the volume of investments in fixed capital per capita and in the opposite direction the factor of unprofitable organizations.

The values of the beta coefficients indicate that the average monthly nominal accrued wages of employees of organizations $(\beta=0.453255)$ and the level of investment in fixed capital per capita (0.383211) have the greatest impact on the level of gross regional product per capita.
Based on a comparison of the actual and calculated by the model value of the gross regional product per capita separately for each subject, it was established that only 11 of the 69 regions included in the aggregate to build the model use the available resources to ensure the possible level of the gross regional product per capita. The Belgorod region also became part of these 11 regions.

The obtained multifactor model was used to predict the gross regional product per capita in the Belgorod Region, which is part of the Central Federal District of the Russian Federation, for the near future. At the same time, in the course of the study, three scenario options for changing the main factors reflecting the resource potential of the region were identified: the inertial scenario, the neutral scenario and the recommended scenario.

The projections of the gross regional product per capita calculated in accordance with the selected scenarios are given in table 4.

Table 4. Prediction of growth factors of the gross regional product per capita in accordance with the selected scenarios

\begin{tabular}{|c|c|c|c|c|c|}
\hline Index & 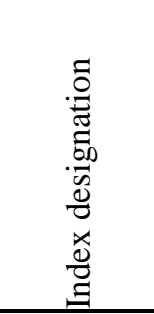 & 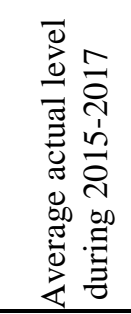 & 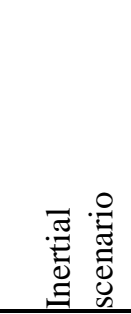 & 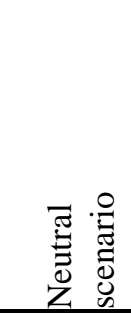 & 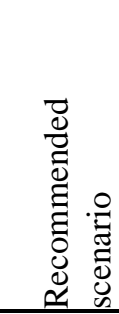 \\
\hline Employment rate, \% & $\mathrm{x}_{3}$ & 66.8 & 67.0 & 68.4 & 69.5 \\
\hline $\begin{array}{l}\text { Average monthly nominal wage of workers assessed } \\
\text { by organization, rub. }\end{array}$ & $\mathrm{x}_{4}$ & 27204 & 32750 & 35000 & 40000 \\
\hline $\begin{array}{l}\text { Amount of investment to the fixed capital per capita } \\
\text { batch, rub. }\end{array}$ & $\mathrm{x}_{6}$ & 92483 & 94700 & 100500 & 131500 \\
\hline Proportion of loss-making organizations, $\%$ & $\mathrm{X}_{8}$ & 27.4 & 27 & 23 & 20 \\
\hline Value of gross regional product, rub. & $\mathrm{y}$ & 474972 & 493200 & 545844 & 665536 \\
\hline \multicolumn{2}{|c|}{$\begin{array}{l}\text { Run-rate changes in comparison with the actual average level } \\
\text { during } 2015-2017, \%\end{array}$} & 100 & 104 & 115 & 140 \\
\hline
\end{tabular}

The inertial scenario reflects a pessimistic variant, which presupposes a change in the values of the main indicators-factors, at a rate lower than the prevailing in recent years. With the implementation of the inertial scenario, the probability of which is low in the modern conditions of regional development, the growth rate of the gross regional product per capita can be only about $4 \%$ compared to the average actual level for 2015-2017.

The recommended scenario assumes the implementation of regional development programs and potentially the size of the gross regional product per capita may increase to 665,536 rubles, which is $40 \%$ higher than the actual average level.

\section{CONCLUSION}

The results of the study indicate a significant differentiation of the components of the resource potential of the regions of the Russian Federation, which determines the high differentiation of the level of gross regional product per capita.

The construction of a multifactor model made it possible to distinguish four factors that sufficiently describe the total variation of the gross regional product per capita. At the same time, the level of gross regional product per capita is directly dependent on factors: the level of employment of the population, the average monthly nominal accrued wages of employees of organizations and the volume of investments in fixed capital per capita and in the opposite direction the factor of unprofitable organizations.

The obtained multifactor model allows simulating possible scenarios of changes in the gross regional product per capita, depending on factors identified in the course of building the model, which can be used in decision making at various levels of government and setting priorities for the socio-economic development of regions. 


\section{REFERENCES}

1. Gerasimov, A.V., Tretyakova, L.A., 2017. Nauchno-obrazovatel'nyj klaster kak mehanizm regional'nogo razvitija [Scientific-educational cluster as a mechanism for regional development]. Ekonomika i predprinimatel'stvo [Economics and entrepreneurship],1 (78): 1026 1030 (In Russian).

2. Heon-Goo Kim, 2008. The Effect of IT Innovation on Industrial Output Elasticities. Hitotsubashi Journal of Economics, 49 (1): 11-22.

3. Howard-Grenville J., 2016. Understanding and tackling societal grand challenges through management research. Academy of Management Journal, 59 (6): 1880-1895.

4. Kuklin, A. A., Korobkov, I. V., 2018. Vybor effektivnoj traektorii social'no-ekonomicheskogo razvitiya regiona [Selection of an Effective Trajectory of Regional Socio-Economic Development]. Ekonomika Regiona [Economy of Region], 14(4): 1145-1155 (In Russian).

5. Kuznetsova, N.V., Kocheva, E.V., Matev ,N.A., 2015. Balance of Economic Development of APR Countries. Journal of Advanced Research in Law and Economics, 3 (13): 584-605.

6. Savaley, V.V., 2017. Valovoj regional'nyj produkt kak indikator effektivnosti i urovnya razvitiya territorial'noj ekonomiki [Gross regional product as an indicator of territorial economy efficiency and development level]. Territoriya novyh vozmozhnostej [The Territory of New Opportunities], 9(2): 31-43 (In Russian).

7. Tretyakova, L.A., Tselyutina, T.V. and etc., 2015. Function Representation of the Civil Society Institutions Within the Transforming Sustainability of the Regional Development. International Business Management, 9 (5): 963-965.

8. Tretyakova, L. A., Vlasova, T. A. and etc., 2018. Formation of the knowledge-intensive clusters as factor of innovative development of russian regions. J. Fundam. Appl. Sci.,10 (4S): 1570-1579.

9. Valentey, S. D., Bakhtizin, A. R., Bukhvald, Ye. M., Kolchugina, A. V., 2014. Trendy razvitiya rossiiskikh regionov [Development trends of the Russian regions]. Ekonomika regiona [Economy of Region], 3: 9-21 (In Russian).

10. Vlasova, T. A., Glotov, D.S., 2018. Prostranstvennaya differenciaciya regionov Central'nogo federal'nogo okruga RF po urovnyu ih konkurentnyh preimushchestv [Spatial differentiation of the regions of the Central Federal District of the Russian Federation by the level of their competitive advantages]. Audit i finansovyj analiz [Audit and financial analysis], 3: 162-166 (In Russian). 